\begin{tabular}{|c|c|c|}
\hline $\begin{array}{l}\text { EXCELLENT } \\
\text { PURI ISHERS }\end{array}$ & $\begin{array}{l}\text { International Journal of Current Research } \\
\text { and Academic Review } \\
\text { ISSN: 2347-3215 (Online);, Nolume 5;, Number } 6 \text { (June-2017) }\end{array}$ & $=$ \\
\hline
\end{tabular}

doi: https://doi.org/10.20546/ijcrar.2017.506.007

\title{
Fossil Gymnosperms-A Review
}

\author{
Teena Agrawal* and Priyanka Danai
}

Banasthali University, Niwai, India

*Corresponding author

\section{Abstract}

Gymnosperm are the plants which have fully exposed ovules not enclosed in the fruit, they have the long evolutionary history. The palaeobotany of the gymnosperms goes from the early Triassic to the late cretaceous. Gymnosperm is the most ancient seed plant that originated during the late paleozoic era and flourish well in the Mesozoic era. The long pathway of the evolution has a number of the lines of the cladistcs and the diverge lines of the evolution at that time a number of the plants of that lineage evolved and other plants group extinct in the liens of the evolution. There are a large group of the gymnosperms who have along linage of the fossil gymnosperms, in this series, pteridopaermales, having lyginopteridaceae, medullasaceae, glsospteridaceae, calamopityaceae, bennettitales are the group having a very long and diverse kind of the evolutionary history. However in that era majority f the gymnosperms' are extinct, they are presented by only the cycadales and conifelraes, gnetlaes.
\end{abstract}

\section{Article Info}

Accepted: 05 June 2017

Available Online: 20 June 2017

\section{Keywords}

Fossil gymnosperms,

Evolution,

Fossil gymnosperms,

Bennttitlaes,

Caytoniales,

Pteridopsermales,

Cladistices.

\section{Introduction}

Evolution of the plants is a very important aspect in the development of the life or biota in the biosphere. In the early proterozoic era, a number of the unicellular and the multicellular algae like organism start evolved in the oceans, this was the first step in the evolution of the plants on the earth (Fig. 1). Later on as the evolution proceeds out the plants start adapting on the lands, in this case different kinds of the adaptation as well as evolution of the many organs starts in the life (Fig. 2). Bryophytes, Pteridophytes, Gymnosperms and Angiosperms are the plants of the evolution, which shows the clear pathway of the development of the organs according to the adaptation of the plants on the lands.

However each series of the plants like algae fungi, Pteridohytes, Gymnosperms and Angiosperms also have a fossil history. In that review articles we are trying to analyse the fossil history of the gymnosperms.

Gymnosperm are the most ancient seed plants, originated during the late Paleozoic era during the upper Devonian time scale, it was the first evolutionary time for the origin of the gymnosperm in the time scale of the plants development. However they flourish well in the Mesozoic time era. during that era gymnosperm speared all over the planet, they can be found on the land, on the air and as well as in the water, however long evolutionary history of the gymnosperm is full of a number of the examples of the living and the extant gymnosperms. In that era we can observe a number of the gymnosperms who were abundant in that era but as the climate changes a rapid decline can be seen in that organism. One of these plants includes the organisms of the ferns like in evolution, they have been termed as the 
Pteridospermales, and they have been resemblance from the early ferns as well as some advances features of the cycads, so that time has been termed as the ages of the cycads.

this was the very large group having the assemblage of the, many kind of the plants having intermediate feature from may kinds' of the plants, here are included a number of the families like the Lyginopterodaceae, Medullasaceae, Caytoniaceae, Calamopitacese, Bennettitales and Pentoxylales.

The modern and the living gymnosperm are place in the following categories like the Cycadophyta, Coniferophyta, Ginkgophyta and Gnetophyta. The
Cycadales and the Ginkgoales includes the long fossil history, among the Ginkgoales all the plants are extinct now only one of the existing genus termed as Ginkgo is living. In Cycadales also most of the members in the lines were degraded, however only 11 genera can be elicited as the living representative of the group. These orders have been termed as the living fossils in the group.

In recent era representative of the gymnosperms are presented by only the Coniferlaes, some of the genera of the conifers are representatives of the gymnosperm, however there distribution is also very restricted, they are distributed only in some part of the world like the northern hemisphere of the globe.

Table.1 Extinct gymnosperms

\begin{tabular}{|l|l|l|l|}
\hline s.no & Extinct group & $\begin{array}{l}\text { Period of } \\
\text { existence }\end{array}$ & $\begin{array}{l}\text { Life span of } \\
\text { millions of years }\end{array}$ \\
\hline 01 & $\begin{array}{l}\text { Palaeozoic } \\
\text { Pteridospermales }\end{array}$ & $\begin{array}{l}\text { Lower } \\
\text { carboniferous to } \\
\text { permian }\end{array}$ & $\begin{array}{l}115 \text { millions of } \\
\text { years }\end{array}$ \\
\hline 02 & $\begin{array}{l}\text { Mesozoic } \\
\text { pteridopsermales }\end{array}$ & $\begin{array}{l}\text { Upper Triassic to } \\
\text { lower cretaceous }\end{array}$ & 90 millions years \\
\hline 03 & Pentoxylales & $\begin{array}{l}\text { Lower Jurassic to } \\
\text { Triassic }\end{array}$ & 25 millions years \\
\hline 04 & Bennettitales & $\begin{array}{l}\text { Triassic to upper } \\
\text { cretaceous }\end{array}$ & 155 millions years \\
\hline 05 & Cordialtes & $\begin{array}{l}\text { Lower } \\
\text { carboniferous }\end{array}$ & 115 millions years \\
\hline 06 & $\begin{array}{l}\text { Extinct } \\
\text { cycadales }\end{array}$ & $\begin{array}{l}\text { Upper cretaceous } \\
120 \text { millions years }\end{array}$ \\
\hline
\end{tabular}

Fig.1 Evolution of the plants

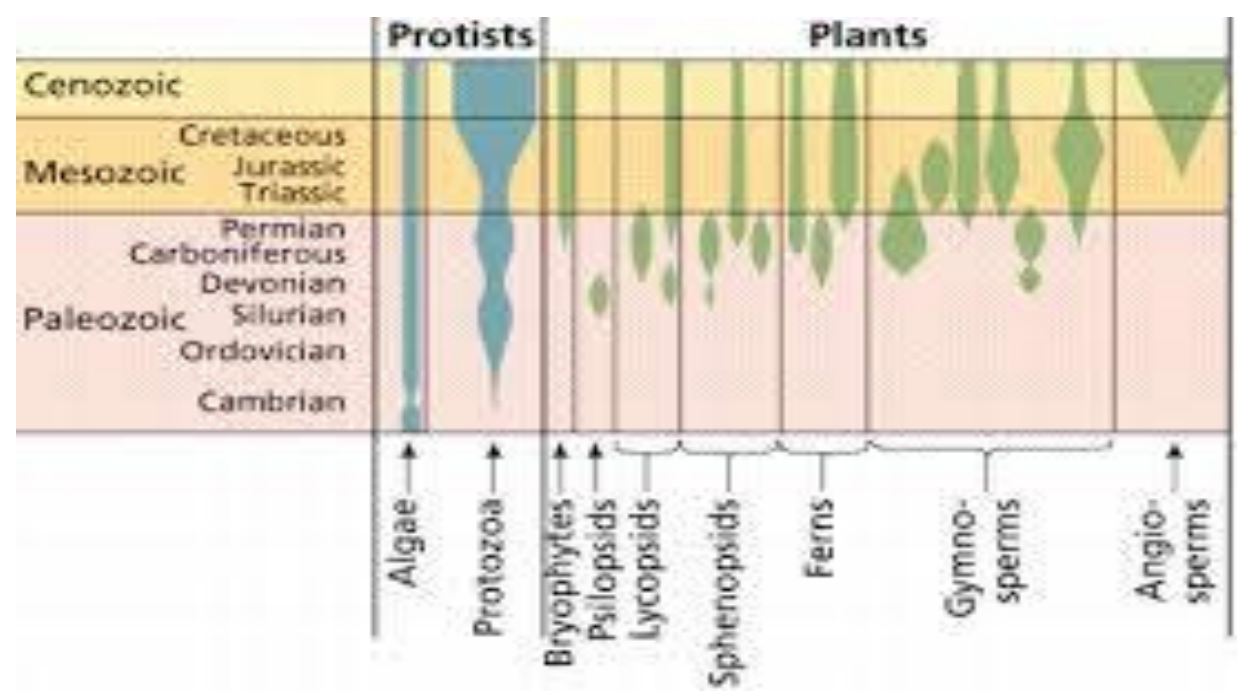


Fig.2 Evolution of the land plants

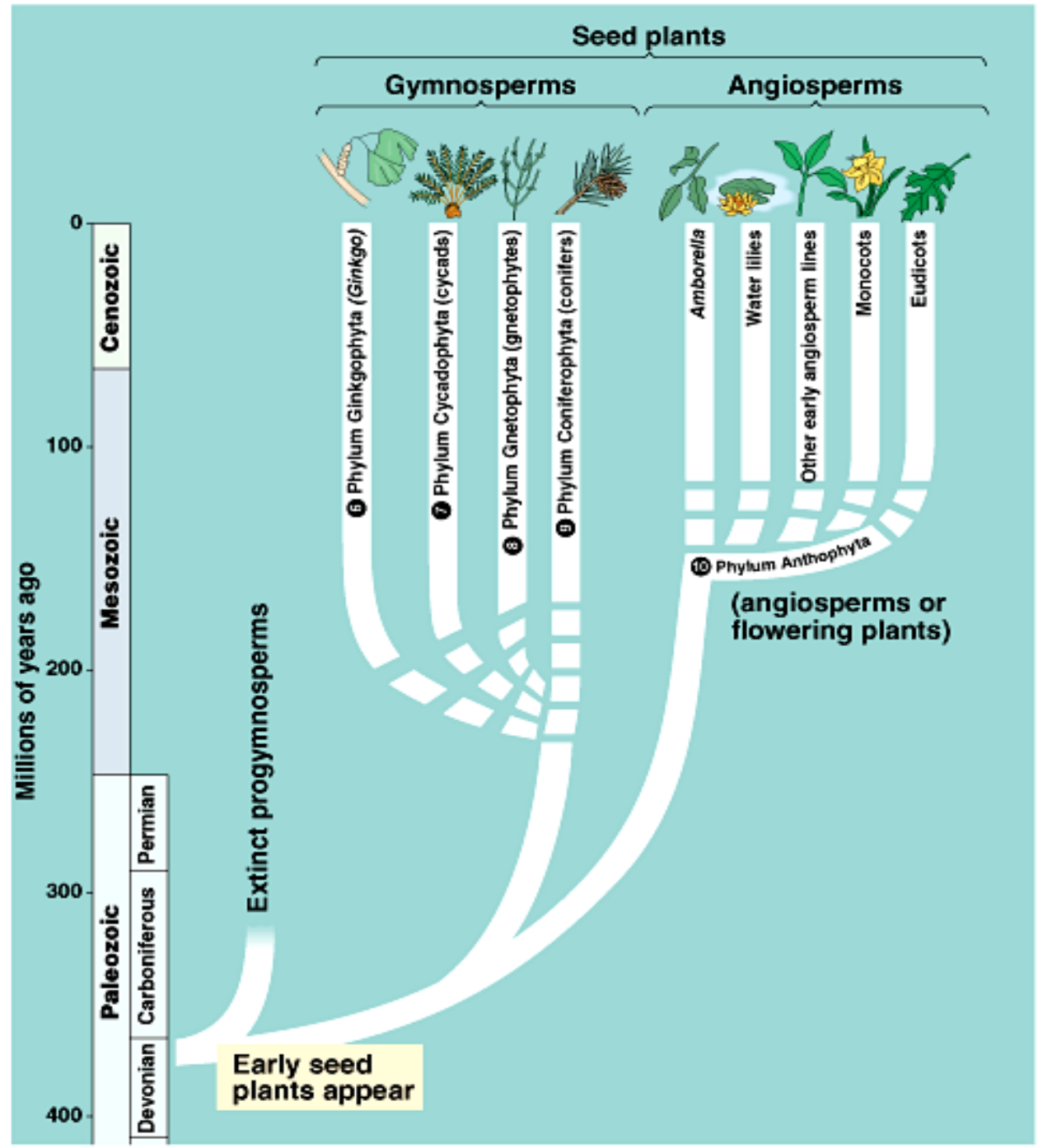

Copyright $\otimes$ Pearson Education, Inc., publishing as Benjamin Cummings.

Fig.3 Pteridospermales ovules (From the Eames)

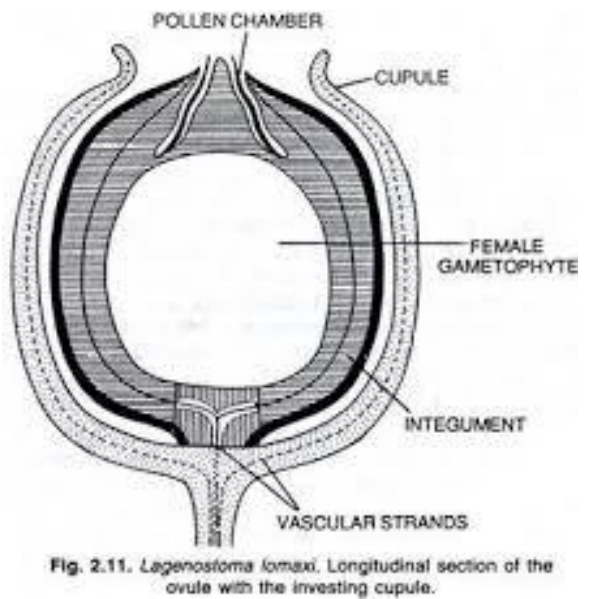


Fig.4 Tree ferns: Pteridospermales

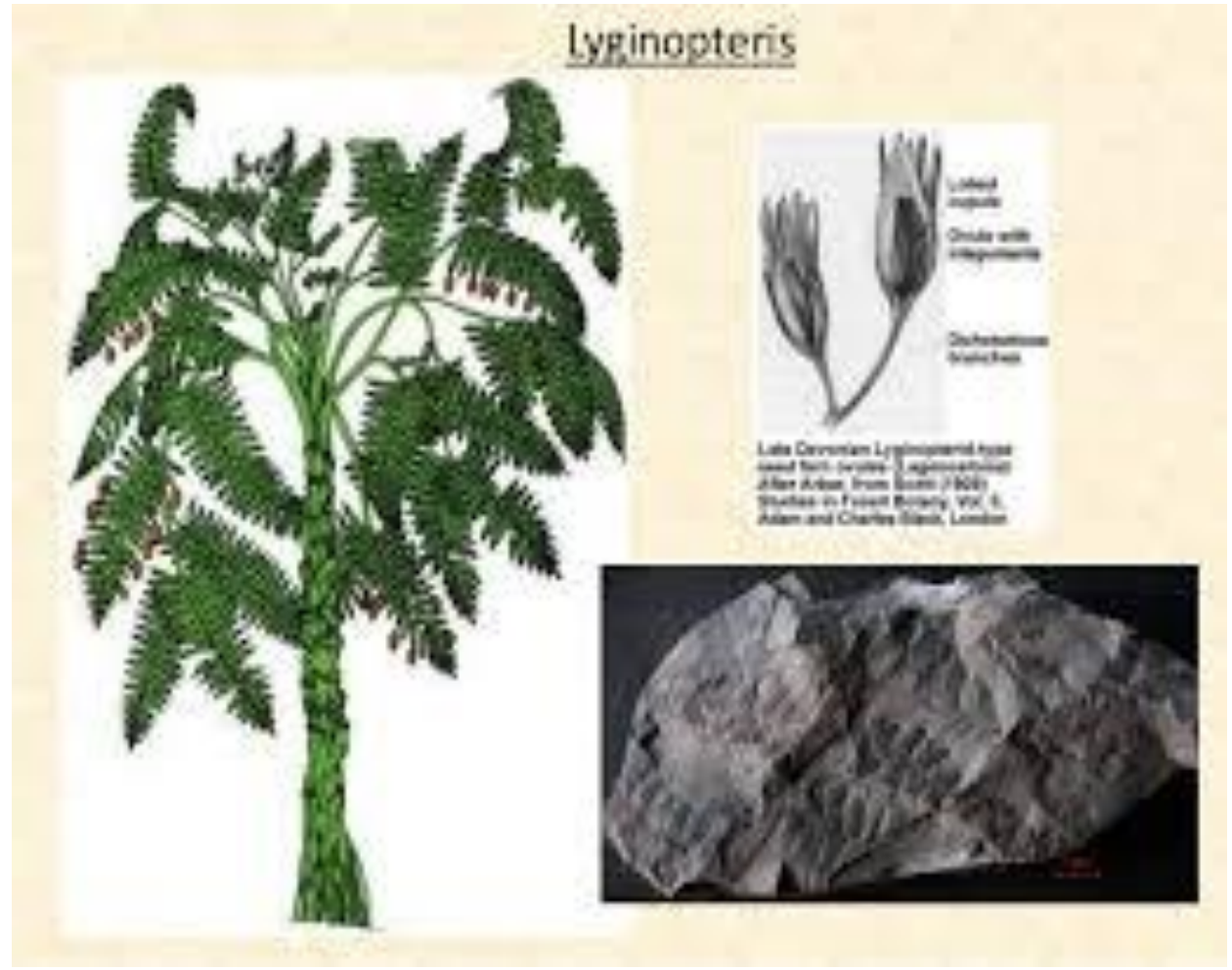

Fig.5 Flowers of the Bennettitales

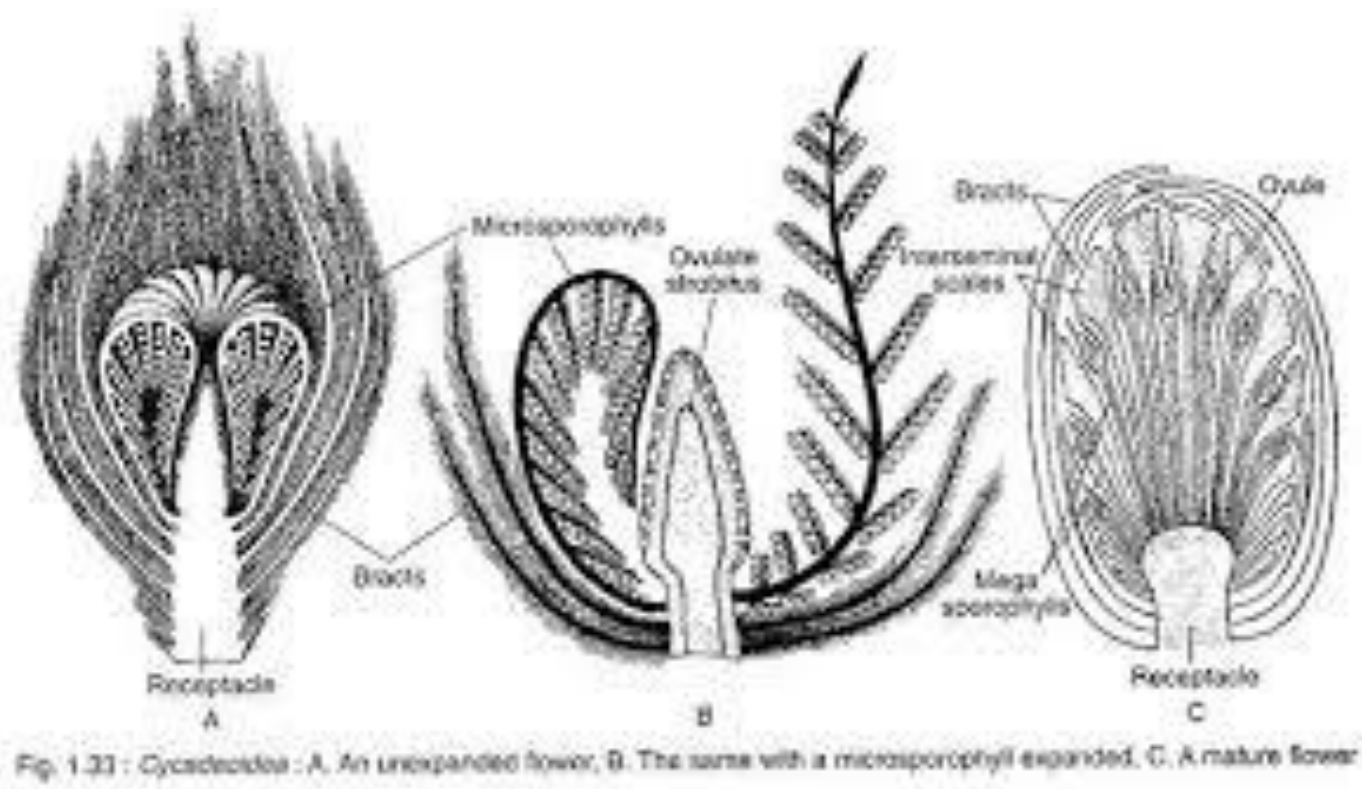


Fig.6 Pentoxylales

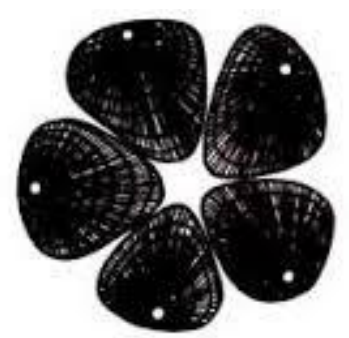

Fig. 7.1. Pentoxylon sahnii, T.S. stele. (after Sahni)

Fig.7 Pentoxylon structures

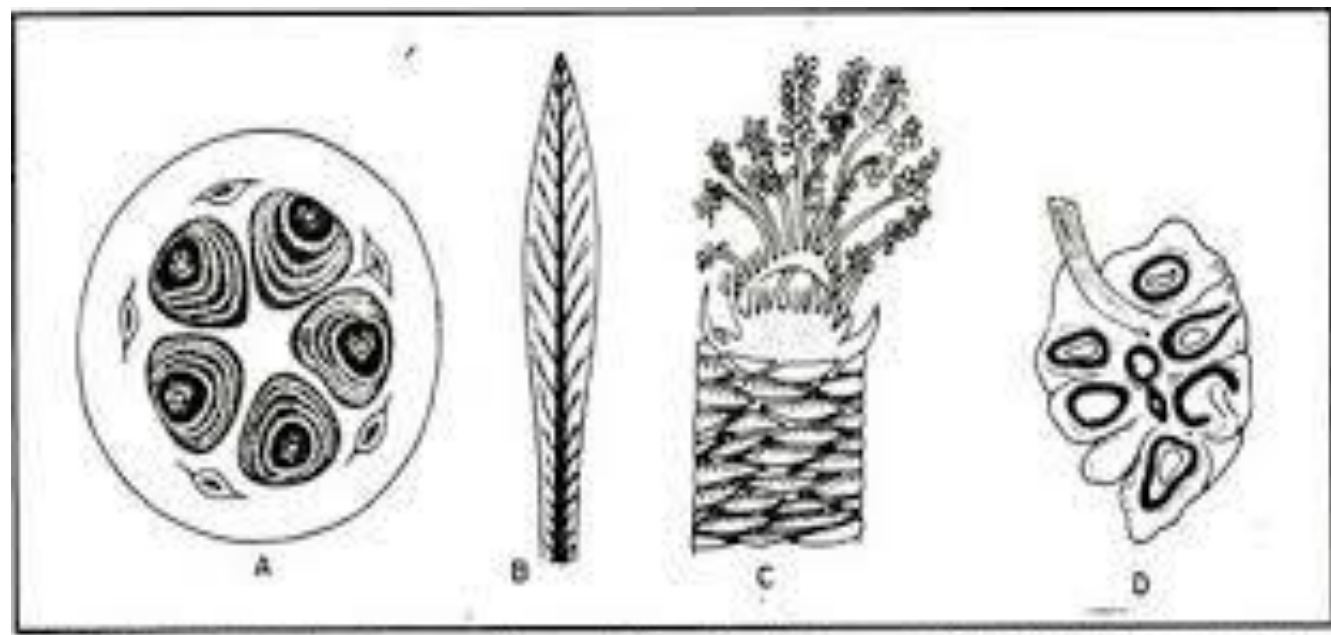

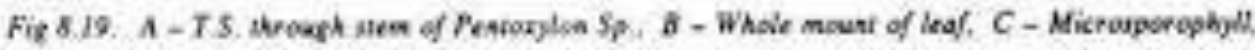

$D-V S$. ahrewet diveles

In India the conifers are distributed in the Uttarakhand area as well Nilgiris hills of the India. However in India also the habitat for the gymnosperms are degrading, so they are represented by only a very a small group.

The Gnetales are presented by the three genera like the: Ephedra, Gnetum and Welwitschia. Gnetum and the Ephedra are distributed in the Asia as well as tropical part of the world. Gnetales is presented by the different lines of the devolution, however they are very close to the angiosperms in distribution as well as they have been considered as the progenitor of the angiosperms. a line of the evolution of the Gnetales is also very different from the other lines of the gymnosperms

Some of the feature of the fossil gymnosperms' is presented by the following orders.

1. Pteridospermales
2. Bennettitales

3. Pentoxylales.

\section{Features of Pteridospermales}

* Pteridospermales are the fern -like plants having the fern like appearance but they have the seeds on their leaves in place of sporangia on the leaves. The seeds are unprotected (Figs. 3 and 4).

* This plant group contains the large assemblages of the many trees like ferns in the group, which were flourishing well during the Upper Carboniferous periods.

* This fascinating group was discovered by the grand Eury in 1877.

* This group is represented by the number of the genera like the Ganagompteris, Glossopteris, Godwandium, Indotheca, Pecopteris and other similar genera. 
* In India and among the other part of the world this group has been analysed by the number of the palaeobotanist.

* This plant group had some of the resemblance from the Pteridophytes and the gymnosperms.

* Pteridospermales is represented by the following families.

* A) Lyginopteridaceae, B) Medullosaceae, C) Calamitaceae, D) corystopsermaceae, E) Caytoniaceae

* Among these families, the three are presented in the Palaeozoic era and the other are represented in the late Mesozoic era.

Some of the genera of the Pteridopsermales are represented by the following genera, Lyginopteris, Medullosa, crosotheca, Telangium, Neruopteris, whittleyasia, caalmopitys and Glossopteridacea.

Bennettitales is the fossil group that has been discovered in the great Britain by the paleobotansit in 1825, the genus was the Bucklandia, these group of the plants has been found in the form of the petrifaction and compression form of the fossil, well the discovery of that group has trace out the pathway of the evolution of the many kind of the gymnosperm and the angiosperms, since this group has a many features of the combinations in characters. This group was well flourished in late Triassic and the early Jurassic period, that age has been termed as the ages of the cycads (Fig. 5).

Some of the features of the Bennettitales are enlisted as.

1. The leaves are large and pinnate, they resemble with the ferns in appearances.

2. The stomata are syndetocheilic.

3. The stem has large pith surrounds by the vascular bundles.

4. The reproductive organs are bisexual. These organs have been termed as the flower like in organization.

5. The Bennettitales have two families.

a) Williamsoniaceae.

b) Cycadaceae.

The third order is represented by the Pentoxylales.

This fossil group has been discovered by the professor Birbal Sahani. It was discovered from the Rajamahal hills of the India from the Jurassic flora of the India. However in the Spornae classification, this order has been represented in different taxa.
This order was discovered in the different from like separated stem, leaves, flower and pollen (Figs. 6 and 7).

Similarly a number of the fossils plants can be seen in the cycadales, however there is a long fossil history of the gymnosperms which can be discussed in detail overall this plant group is very fascinating, and we have to conserve these lines of the evolutions, since due to changes in the habitat and rapid degradation of the habitat, these groups are get extinction with the great speed, by the biotechnological conservations methods these groups need more protection and establishment.

\section{References}

Zamiidae Doweld, Tent. Syst. Pl. Vasc.: xv (2001).—T.: Zamiaceae.

Zamiales Burnett, Outl. Bot.: 490 (1835).-T.: Zamiaceae.

Stangeriales Doweld, Tent. Syst. Pl. Vasc.: xv (2001).T.: Stangeriaceae. 1 genus, ca 107 species, East Africa to Japan and Australia.

Todda-Pana Adans., Fam. 2: 25. (1763), nom. illeg. by typification.-T.: Cycas circinalis L. Dyerocycas Nakai, Chosakuronbun Mokuroku [Ord. Fam. Trib. Nov.] 208 (1943).-T.: D. micholitzii (Dyer) Nakai Cycas micholitzii Dyer).

Epicycas de Laub. in D.J. de Laubenfels \& F.A.C.B. Adema, Blumea 43: 388 (1998), nom. illeg.-T.: E. micholitzii (Dyer) de Laub. (Cycas micholitzii Dyer). 9 genera, ca 206 species, tropical and subtropical Africa, Australia and America. The phylogenetic tree followed here is that of Zgurski et al. (2008).

Encephalartaceae Schimp. and Schenk in K.A. Zittel, Handb. Palaeontol., Palaeophyt. 2: 215 (1880).-T: Encephalartos Lehm.

Stangeriaceae Schimp. and Schenk in K.A. Zittel, Handb. Palaeontol., Palaeophyt.: 216 (1880).-T.: Stangeria T.Moore Boweniaceae D.W.Stev., Amer. J. Bot. 68: 1114 (1981).—T.: Bowenia Hook.f.

Dioaceae Doweld, Tent. Syst. Pl. Vasc.: xv. ( 2001).T.: Dioon Lindl. Microcycadaceae Tarbaeva, Anat.Morf. Str. Sem. Cycad.: 19 (1991).—T: Microcycas (Miq.) A.DC.

Platyzamia Zucc., Abh. Math.-Phys. Cl. Königl. Bayer. Akad. Wiss. 4(2): 23 (1845).-T.: P. rigida Zucc.

Palma-Filix Adans., Fam. 2: 21, 587 (1763), nom. rej. Aulacophyllum Regel, Gartenflora 25: 140 (1876).-T.: A. skinneri (Warsz.) Regel (= Zamia skinneri Warsz.) 
Palmifolium Kuntze, Rev. Gen. 2: 803 (1891), nom. illeg. (= Palma-Filix Adans., nom. rej. = Zamia L., nom. cons.) Chigua D.W.Stev., Mem. New York Bot. Gard. 57: 170 (1990).--T.: C. restrepoi D.W.Stev. (= Zamia restrepoi (D.W.Stev.) A.J.Lindstr.), see Lindstrom (2009). 1 genus, 1 extant species, China.

Salisburia Sm., Trans. Linn. Soc. London 3: 330 (1797), nom. illeg.-T.: S. adiantifolia Sm. (= Ginkgo biloba L.) Pterophyllus J.Nelson, Pinaceae: 163 (1866), nom. illeg., non Lév. (1844, Agaricaceae).-T.: P. salisburiensis J.Nelson, nom. illeg. (= Ginkgo biloba L.) Ephedridae Cronquist, Takht. \& Zimmerm. ex Reveal, Phytologia 79: 69 (1996).-T.: Ephedraceae.

Welwitschiidae Cronquist, Takht. \& Zimmerm. ex Reveal, Phytologia 79: 71 (1996).-T.: Welwitschiaceae.

Tumboaceae Wettst., Handb. Syst. Bot. 2(1): 158 (1903).-T: Tumboa Welw., nom. rej. (= Welwitschia Hook.f., nom. cons.) 1 genus, 1 species, Namibia, Angola.

\section{How to cite this article:}

Teena Agrawal, Priyanka Danai. 2017. Fossil Gymnosperms. Int.J.Curr.Res.Aca.Rev. 5(6), 49-55.

doi: https://doi.org/10.20546/ijcrar.2017.506.007
Tumboa Welw., Gard. Chron. 1861: 75. (1861), nom. rej. Thoaceae Kuntze in T.E. von Post \& C.E.O. Kuntze, Lex. Gen. Phan.: 615 (1903).-T.: Thoa Aubl. 1 genus, 30 species, India, Malesia, tropical West Africa, Amazonian South America.

Thoa Aubl., Hist. Pl. Guiane: 874 (1775).-T.: T. urens Aubl. Abutua Lour., Fl. Cochinch.: 630 (1790).T.: A. indica Lour. Gnemon [Rumpf ex] Kuntze, Rev. Gen. 2: 796 (1891), nom. Illeg.-T.: G. ovalifolia O.Kuntze (= Gnetum gnemon L.) 1 genus, ca 40 species, Mediterranean Europe, North Africa, warm temperate Asia, North America and western South America.

Chaetocladus J.Nelson, Pinaceae: 161 (1866), nom. Illeg.-T.: C. distachyus (L.) J.Nelson (as 'distachys') = Ephedra distachya L.

Taxidae Ehrend. Ex Reveal, Phytologia 79: 71 (1996).T.: Taxaceae.

Podocarpidae Doweld \& Reveal, Phytologia 84: 366 (1999).-T.: Podocarpaceae.

Araucariidae Doweld, Tent. Syst. Pl. Vasc.: xx (2001).T.: Araucariaceae. 